\title{
Orthogonal $\mathrm{Cu}$ - and Pd-Based Catalyst Systems for the O- and N-Arylation of Aminophenols
}

\author{
Debabrata Maiti and Stephen L. Buchwald \\ Department of Chemistry, Massachusetts Institute of Technology, Cambridge, Massachusetts \\ 02139
}

\begin{abstract}
$\mathrm{O}$ - or $\mathrm{N}$-arylated aminophenol products constitute a common structural motif in various potentially useful therapeutic agents and/or drug candidates. We have developed a complementary set of $\mathrm{Cu}$ - and $\mathrm{Pd}$-based catalyst systems for the selective $\mathrm{O}$ - and $\mathrm{N}$-arylation of unprotected aminophenols using aryl halides. Selective O-arylation of 3-and 4-aminophenols is achieved with copper-catalyzed methods employing picolinic acid or CyDMEDA, trans- $N, N^{\prime}$-dimethyl-1,2cyclohexanediamine, respectively, as the ligand. The selective formation of $\mathrm{N}$-arylated products of 3- and 4-aminophenols can be obtained with BrettPhos precatalyst, a biarylmonophosphine-based palladium catalyst. 2-Aminophenol can be selectively N-arylated with CuI, although no system for the selective O-arylation could be found. Coupling partners with diverse electronic properties and a variety of functional groups can be selectively transformed under these conditions.
\end{abstract}

\section{Introduction}

Transition metal-catalyzed carbon-heteroatom bond-forming reactions are widely used in industry and academia in pharmaceutical research, materials synthesis, and process development. $1^{-} 7$ Over the past few years our laboratory has focused on the development of effective and user-friendly systems for $\mathrm{Pd}$ - and $\mathrm{Cu}$-catalyzed cross-coupling reactions. $1,8,9$ The substrate scope and generality of these processes has improved to the point where many chemoselective $\mathrm{C}-\mathrm{O}, \mathrm{C}-\mathrm{N}$ and $\mathrm{C}-\mathrm{C}$ coupling reactions can be performed without the need to employ protecting groups. For example, we have reported the selective $\mathrm{N}$ - or $\mathrm{O}$-arylation of aminoalcohols 10,11 and the C- or N-arylation of oxindoles.12 In this context, we considered aminophenol derivatives to be interesting targets for chemoselective metal-catalyzed crosscoupling reactions with aryl halides (Scheme 1) because of the difference in acidity of $\mathrm{PhOH}\left(\mathrm{p} K_{\mathrm{a}} \sim 18\right.$ in DMSO) and $\mathrm{PhNH}_{2}\left(\mathrm{p} K_{\mathrm{a}} \sim 31\right.$ in DMSO).13

O- or $\mathrm{N}$-arylated aminophenol products constitute a common structural motif in various potentially useful therapeutic agents and/or drug candidates (Figure 1).14-22 They have also been applied as building blocks for the preparation of organic materials. $23 \mathrm{We}$ were interested in developing a catalytic system capable of selectively arylating either the nitrogen or the oxygen of the different isomers of aminophenols.

sbuchwal@mit.edu.

Supporting Information Available: Experimental procedures and characterization data for all new and known compounds. This material is available free of charge via the Internet at http://pubs.acs.org. 


\section{Results}

\section{Cu-Catalyzed O-Arylation of 3-Aminophenol}

We began our studies by examining the selective $\mathrm{O}$ - or $\mathrm{N}$-arylation of 3-aminophenol. The use of previously published conditions for $\mathrm{Cu}$ - or $\mathrm{Pd}$-catalytzed O-arylation reactions of phenols 3,4,24 met with limited success. Formation of the $\mathrm{N}$-arylated product or a mixture of $\mathrm{N}$ - and $\mathrm{O}$-arylated products was observed.

After some experimentation, we discovered that a copper catalyst derived from $5 \mathrm{~mol} \% \mathrm{CuI}$, $10 \mathrm{~mol} \%$ picolinic acid 1 (Figure 2),25,26 and $2.0 \mathrm{mmol} \mathrm{K}_{3} \mathrm{PO}_{4}$ in dimethylsulfoxide (DMSO) could catalyze the O-arylation of 3-aminophenols with aryl iodides in excellent yields and with high levels of chemoselectivity under mild conditions (Table 1, entry 1).

Using these reaction conditions, no N-arylated products were detected by GC-MS analysis of the crude reaction mixture. Reactions employing various other ligands (Table 1) including pyrrole-2-carboxylic acid 3,27 and its derivatives $\mathbf{4}$, and $\mathbf{5}$ as well as proline $\mathbf{6}, 28$ under otherwise identical reaction conditions gave $\mathrm{N}$-arylated or mixtures of $\mathrm{N}$ - and $\mathrm{O}$-arylated products.

To probe the generality of this system using $\mathbf{1}$ as the ligand, we evaluated the coupling of compounds with different electronic and steric demands. Electron-rich, -deficient and neutral aryl iodides (Table 2) were all suitable substrates and provided the corresponding diaryl ethers in good to excellent yields. In addition, the presence of an ortho methyl group on the aryl halide was well tolerated (Table 2, entry 6a). Substrates bearing ester and nitrile groups were also transformed to the desired products in good yield (Table 2, entries 8a and 9a).

Aryl bromides could be utilized in these cross coupling reactions, albeit in lower yields (Table 2, entries 2b, 3b, 5b, 9a, 21a and 22a). Aryl chlorides were not suitable coupling partners under these conditions. The differences in reactivity allowed us to selectively couple 4-chloroiodobenzene to generate the corresponding O-arylated products (Table 2, entries $7 \mathrm{a}$ and 17a).

We next explored the O-arylation of both 2- and 6-substituted 3-aminophenols. We found that 5-amino-o-cresol could be efficiently O-arylated with substituted aryl iodides (Table 2, entries 10a, 11a, 12a and 13a). The efficiency of this system was further demonstrated by the selective O-arylation of 3-amino-o-cresol with several substituted aryl iodides (Table 2, entries 14a, 15a and 16a). No $\mathrm{N}$-arylated products were observed in the crude reaction mixtures. The cross-coupling reactions of iodopyridines, iodothiophenes, bromoquinolines and bromoisoquinolines with 3 -aminophenols were also explored. Using the standard protocol, we were able to obtain heteroaryl ethers in good yield (Table 2, entries 18a, 19a, 20a and 21a). Reduction product ( $\mathrm{ArI} \rightarrow \mathrm{ArH}$ ) was detected in some cases, e.g. pyridine (15 $\%$ GC-yield, entry 19a, Table 2) and quinoline (10\% GC-yield, entry 21a, Table 2) and constituted the major byproduct.

\section{Pd-Catalyzed N-Arylation of 3-Aminophenol}

Recently we reported that precatalyst $\mathbf{8}$ based on BrettPhos 7 provides a highly efficient catalyst for C-N cross-coupling reactions (Figure 3).29,30 Such catalysts have been shown to allow the coupling of anilines and aryl halides with short reaction times and low catalyst loadings. We found that employing $0.2 \mathrm{~mol} \% 8$ with $\mathrm{NaO} t$-Bu in 1,4-dioxane at $90{ }^{\circ} \mathrm{C}$ in the reactions of aryl bromides and chlorides with 3 -aminophenols cleanly led to the $\mathrm{N}$-arylation products. This, combined with our above-described copper method constitutes an orthogonal set of catalysts for the selective $\mathrm{N}-(\mathrm{Pd})$ or $\mathrm{O}-(\mathrm{Cu})$ arylation of 3-aminophenols. 
As shown in Table 2, electron-rich, -deficient and -neutral aryl bromides underwent $\mathrm{N}$ arylation in excellent yields and with high levels of chemoselectivity using 8 (Table 2, entries $1 b, 2 c, 3 c, 4 b$ and $5 c$ ). The selective $\mathrm{N}$-arylation of 3 -aminophenol was also successful with 2-substituted aryl halides (Table 2, entry 6 b). The use of $\mathrm{NaO} t$-Bu precludes the presence of base-sensitive functional groups, however, the weak base $\mathrm{K}_{2} \mathrm{CO}_{3}$ can be used in $t$ - $\mathrm{BuOH}$ with BrettPhos precatalyst 8 at a slightly higher temperature $\left(110^{\circ} \mathrm{C}\right)$ and with longer reaction times $(80 \mathrm{~min})$. A variety of functional groups were tolerated, including an ester and a nitrile (Table 2, entries $8 \mathrm{~b}$ and $9 \mathrm{~b}$ ).

An aryl chloride could also be present in either the nucleophilic or electrophilic coupling partner (Table 2, entries $7 \mathrm{~b}$ and 17b). As with O-arylation, substituted aminophenols were successfully $\mathrm{N}$-arylated (Table 2, entries 10b, 11b, 12b, 13b, 14b, 15b, 16b and 17b), thus complementing the $\mathrm{Cu}$-catalyzed $\mathrm{O}$-arylation process described above. Heteroaryl bromides containing pyridines, thiophenes, quinolines and isoquinolines were all selectively $\mathrm{N}$ arylated in good to excellent yields (Table 2, entry 18b, 19b, 20b and 21b).

In all of the cases examined, aryl chlorides behaved similarly to aryl bromides in their selective $\mathrm{N}$-arylation with 3 -aminophenols under these conditions (Table 2, entries $6 \mathrm{c}, 8 \mathrm{c}$, $9 \mathrm{c}, 12 \mathrm{c}, 13 \mathrm{c}$ and $16 \mathrm{c})$. The faster rate of oxidative addition of $\operatorname{LPd}(0)$ to the aryl bromide allowed for the selective amination of chlorobromo substrates (Table 2, entries $7 \mathrm{~b}$ and 17b).

\section{Cu-Catalyzed O-Arylation of 4-Aminophenol}

Following our success with 3-aminophenol, we set out to find conditions that would allow analogous transformations of 4-aminophenol. While the combination of CuI with 1 promotes the O-arylation of 4-aminophenol in 1,4-dioxane with $\mathrm{K}_{3} \mathrm{PO}_{4}$ or $\mathrm{Cs}_{2} \mathrm{CO}_{3}$, the reactions proceed in low yield. The use of all the ligands shown in Table 1 resulted in formation of the $\mathrm{N}$-arylated and $\mathrm{N}, \mathrm{N}$-diarylated products and a trace of the O-arylated products. Next, a series of ligands previously employed by our group in copper-catalyzed reactions were examined.27,31 We found that the O-arylated 4-aminophenol could be isolated as the major product with trans- $N, N^{\prime}$-dimethyl-1,2-cyclohexanediamine (CyDMEDA 2, Figure 2),9,32-36 using a variety of solvent and base combinations. Unfortunately, formation of the reduction product $\mathrm{ArI} \rightarrow \mathrm{ArH}$, e.g, $14 \%$ GC-yield of $m$ xylene in entry $3 \mathrm{a}$ and $16 \%$ GC-yield of anisole in entry $6 \mathrm{a}$, Table 3 ) and/or traces of Narylated product could not be completely prevented in most of the cases examined. Further optimization indicated that the combination of butyronitrile as solvent and $\mathrm{K}_{2} \mathrm{CO}_{3}$ as base afforded the highest yield and selectivity for $\mathrm{O}$-arylation. Increasing the temperature above $70{ }^{\circ} \mathrm{C}$ led to increased reduction of the aryl halide; decreasing the reaction temperature resulted in slower reaction rates. In a typical protocol, $10 \mathrm{~mol} \% \mathrm{CuI}, 20 \mathrm{~mol} \% 2$ and $\mathrm{K}_{2} \mathrm{CO}_{3}$, in butyronitrile at $70{ }^{\circ} \mathrm{C}$ were employed along with the aryl iodide and 4-aminophenol (Table 3).

As shown in Table 3, under these conditions the reaction tolerates a number of different substituents either on the nucleophile or electrophile. Systematic variation of the substituents on the aryl halide from the para (entry 2a) to the meta (entries 3a) and ortho positions (entry 4a) provided the corresponding O-arylated products of 4-aminophenol. Functional groups such as ketones and esters, both on the aminophenol and on the aryl iodide, were tolerated (Table 3, entries 7a, 8a, 9a and 14a). Heteroaryliodides such as 2-iodopyridines could be Oarylated in good yield (Table 3 , entry 15a). Substituted 4-aminophenols were shown to provide the desired products in moderate yields (Table 3, entries 5a, 6a, 7a, 8a, 9a, 10a, 11a, 12a, 13a and 14a) as did 4-aminophenols with fluoride or chloride substituents (Table 3, entry 6a, 8a, 9a, 10a and 11a). The reaction of 2-methyl-4-aminophenol (entry 5a) gave a low yield of $\mathrm{O}$-arylated product and produced a significant quantity of the $\mathrm{N}$-arylated compound (16\%). Here an ortho methyl substituent is problematic, possibly due to reduced 
binding efficiency of oxygen to the $\mathrm{Cu}$ center owing to steric interactions. We currently have no explanation for why complete selectivity is seen with 5-amino-o-cresol (Table 2, entry 10a), but not with 2-methyl-4-aminophenol (Table 3, entry 5a).

As with 3-aminophenol, the use of aryl bromides as coupling partners (Table 3, entries $2 \mathrm{~b}$ and $3 b$ ) resulted in lower yields of the desired products.

\section{Pd-Catalyzed N-Arylation of 4-Aminophenol}

As is the case of 3-aminophenols, we found that the use of $0.2 \mathrm{~mol} \% \mathbf{2}$ in combination with $2.5 \mathrm{mmol} \mathrm{NaO} t$-Bu (or $\mathrm{K}_{2} \mathrm{CO}_{3}$ ) in 1,4-dioxane (or $t-\mathrm{BuOH}$ ) at $110{ }^{\circ} \mathrm{C}$ (Table 3) catalyzed the selective $\mathrm{N}$-arylation of 4-aminophenols with aryl bromides and chlorides. As can be seen, 4-aminophenol and substituted analogues could be coupled with a variety of substituted aryl halides to give the $\mathrm{N}$-arylated products in excellent yields and with high levels of chemoselectivity. No products resulting from O-arylation, reduction, or homocoupling of the aryl halide were observed by GC-MS analysis of the crude reaction mixtures.

Of particular interest is entry $4 \mathrm{~b}$ (Table 3 ) in which an ortho-substituted aryl halide was chemoselectively coupled at the $\mathrm{N}$ terminus of 4 -aminophenol. This electrophile is an excellent substrate for Pd-catalyzed diaryl ether synthesis, 24,37,38 emphasizing the preference of the palladium catalyst in this system for C-N over C-O bond formation. 4Amino-3-chlorophenol could be selectively N-arylated with keto-, ester-, or chlorosubstituted aryl halides (Table 3, entries $8 \mathrm{~b}, 9 \mathrm{~b}, 10 \mathrm{~b}$ and $11 \mathrm{~b}$ ). The presence of an ortho fluoride group in the aminophenol moiety did little to decrease the efficiency of its coupling reaction (Table 3, entry 6b). Not surprisingly, 4 -aminophenol could also be selectively Narylated with aryl chlorides (Table 3 , entries $4 \mathrm{c}, 5 \mathrm{c}, 12 \mathrm{c}$ and $13 \mathrm{c}$ ).

\section{Arylation of 2-Aminophenol}

The desired $\mathrm{N}$-arylation reaction of 2-aminophenol could be achieved by using 2aminophenol itself as the ligand for copper (Table 4), giving a good to excellent yield of the mono N-arylation product in 1,4-dioxane at $110^{\circ} \mathrm{C}$. The formation of 3-7\% N,N-diarylated product, however, was unavoidable in most of the cases.39 In all the examples in Table 4, not only was the desired $\mathrm{N}$-arylated product produced in excellent yield, but no trace of the $\mathrm{O}$-arylated product was observed in the crude reaction mixture. The method was also extended to iodopyridines as electrophile (Table 4, entries 6, 7 and 8) in good to excellent yields.

We were unable to find conditions for selective O-arylation of 2-aminophenols presumably due to its abiltity to form a five-membered chelate ring39 with $\mathrm{Cu}$ or Pd. Following screening of many combinations of ligands, solvents, and bases, we found that $10 \mathrm{~mol} \% \mathrm{CuI}$ in DMSO at $120{ }^{\circ} \mathrm{C}$, with 1 equiv of $\mathbf{1}$ as a ligand for copper to outcompete 2-aminophenol as ligand, provided only a $20 \%$ GC yield of the desired O-arylation. Note that a similar result was seen in our previous studies on the $\mathrm{Cu}$-catalyzed arylation of aminoalcohols. 10

\section{Intial Studies Toward Determining the Origin of the Observed Selectivity}

When we carried out a competition experiment in which we reacted a 1:1 mixture of aniline:phenol with chlorobenzene in the presence of $8\left(80^{\circ} \mathrm{C}, 30 \mathrm{~min}\right)$, diphenylamine was the sole product; no formation of diphenylether was observed. Presumably under these conditions Pd-O bond formation is faster than Pd-N bond formation. However, this step is reversible and reductive elimination to form $\mathrm{C}-\mathrm{N}$ bonds is much faster than that to form $\mathrm{C}-\mathrm{O}$ bonds. $24,37,40^{-} 44$ 
In the reaction between a 1:1 mixture of aniline:p-substituted phenol and 4-iodotoluene with a catalyst sytem based on $\mathrm{CuI}$ and picolinic acid $\mathbf{1}$ only diaryl ethers, $p$-tolOAr $\mathbf{A 1}$ and no $\mathrm{N}$-arylation products, $p$-tolN(H)Ph A2, were obtained (Scheme 3). Similarly, in analogous competition experiments with a 1:1 mixture of phenol: $p$-substituted aniline reacting with 4iodotoluene only diaryl ether $\mathbf{B} 1$ was again observed when the aniline substituent $\mathrm{R}^{\prime}=\mathrm{H}, t$ $\mathrm{Bu}$ and $\mathrm{OCH}_{3}$ (Scheme 4). However, in competition experiments between 1:1 phenol:electron-deficient anilines where the aniline substituent $\mathrm{R}^{\prime}=\mathrm{CN}$ and $\mathrm{NO}_{2}$, (Scheme 4), diarylamines, $p$-tolN(H)Ar B2 were obtained as the major product (B1:B2 1:7).

Previous studies of $\mathrm{Cu}$-catalyzed $\mathrm{C}-\mathrm{N}$ bond formation with amides suggest that the binding of the nucleophile to the ligand-copper complex I to form II facilitates its deprotonation to produce complex III prior to aryl halide activation (Scheme 2).45,46 Under our reaction conditions the phenol is converted to the phenoxide prior to binding to the copper center. In contrast, the free aniline is not deprotonated under these conditions. If the equilibration between IIIa and IIIb is slow relative to their rate of oxidative addition, the relative rate of formation of IIIa and IIIb should be selectivity determining. This is also consistent with our observation that in the competition experiments (see above) anilines with electronwithdrawing substituents give mainly diarylamine: once the acidity of the $\mathrm{ArNH}_{2}$ is enhanced with an electron-withdrawing group so that its $\mathrm{pK}_{\mathrm{a}}$ is comparable to that of phenol,13 the free aniline can be deprotonated under the reaction conditions and the resulting anilide ion is comparable in nucleophilicty to the phenoxide.47 In this instance, equilibration between IIIa and IIIb presumably is faster than oxidative addition. Little is known about the relative rate of oxidative addition of IIIa and IIIb. However, Paine has demonstrated that electron-deficient diaryl amines react faster than electron-rich ones.48

\section{Application of This Methodology}

This methodolgy is applicable to the synthesis of a number of potentially useful compounds (Figure 4). Examples of interest include 9, used in the synthesis of polyimide tubes, 49 and 10, found in polyimide crystalline lenses, 50 both of which can be generated in good yields by reacting 3-aminophenol and the appropriate diiodoarene. Compound 11 (Table 2, entry 2c) and 12, oxidative hair dyeing agents, 51 13, protection from scald,52 14, a cytochrome P450 (CYP450) inhibitor,53 15, a polymerization substrate,50 and 16, used in polyimide films, 50 were also prepared using our $\mathrm{Cu}$-catalyzed $\mathrm{O}$-arylation method.

\section{Conclusion}

In summary, we have developed an efficient and complementary set of $\mathrm{Cu}$ - and $\mathrm{Pd}$-based catalyst systems for the selective $\mathrm{O}$ - and $\mathrm{N}$-arylation of unprotected aminophenols using aryl halides. Selective O-arylation of 3-and 4-aminophenols is achieved with copper-catalyzed methods employing picolinic acid 1 or CyDMEDA $\mathbf{2}$, respectively, as the ligand. The selective formation of $\mathrm{N}$-arylated products of 3-and 4-aminophenols could be obtained with BrettPhos precatalyst 8. 2-Aminophenol could be selectively $\mathrm{N}$-arylated with $\mathrm{CuI}$, although no system for the selective O-arylation could be found. Coupling partners with diverse electronic properties and a variety of functional groups can be selectively transformed under these conditions. These methods are likely to find considerable application due to the presence of both $\mathrm{N}$ - and $\mathrm{O}$-arylated aminophenols in important organic compounds. Further studies in the chemoselective arylation of different functional groups and the origin of their selectivity are ongoing in our laboratory.

\section{Supplementary Material}

Refer to Web version on PubMed Central for supplementary material. 


\section{Acknowledgments}

This activity is supported by an educational donation provided by Amgen (postdoctoral fellowship to D.M.) and by funds from the National Institutes of Health (Grant GM-58160). We are grateful to Dr. David Surry and Dr. Tom Kinzel for comments and help with this manuscript. The NMR instruments used for this study were furnished by funds from the National Science Foundation (CHE 9808061 and DBI 9729592).

\section{References}

1. Martin R, Buchwald SL. Acc Chem Res. 2008; 41:1461-1473. [PubMed: 18620434]

2. Jiang, L.; Buchwald, SL. Metal-Catalyzed Cross-Coupling Reactions. 2. de Meijere, A.; Diederich, F., editors. Wiley-VCH; Weinheim, Germany: 2004.

3. Ley SV, Thomas AW. Angew Chem, Int Ed. 2003; 42:5400-5449.

4. Beletskaya IP, Cheprakov AV. Coord Chem Rev. 2004; 248:2337-2364.

5. Hartwig JF. Acc Chem Res. 2008; 41:1534-1544. [PubMed: 18681463]

6. Ma DW, Cai QA. Acc Chem Res. 2008; 41:1450-1460. [PubMed: 18698852]

7. Evano G, Blanchard N, Toumi M. Chem Rev. 2008; 108:3054-3131. [PubMed: 18698737]

8. Surry DS, Buchwald SL. Angew Chem, Int Ed. 2008; 47:6338-6361.

9. Klapars A, Huang XH, Buchwald SL. J Am Chem Soc. 2002; 124:7421-7428. [PubMed: 12071751]

10. Shafir A, Lichtor PA, Buchwald SL. J Am Chem Soc. 2007; 129:3490-3491. [PubMed: 17341083]

11. Job GE, Buchwald L. Org Lett. 2002; 4:3703-3706. [PubMed: 12375923]

12. Altman RA, Hyde AM, Huang X, Buchwald SL. J Am Chem Soc. 2008; 130:9613-9620. [PubMed: 18588302]

13. Bordwell FG, Algrim DJ. J Am Chem Soc. 1988; 110:2964-2968.

14. Bird, TGC. Patent PCT Int Appl. WO 2002085868. 2002.

15. Furusako, S.; Satoh, T.; Nakamura, M.; Mizuno, M.; Mori, S. Patent PCT Int Appl. WO 2003087072. 2003.

16. Zavitz, K. Patent PCT Int Appl. WO 2004091522. 2004.

17. Glazko AJ, Chang T, Borondy PE, Dill WA, Young R, Croskey L. Curr Ther Res Clin Exp. 1978; 23:S22-S41.

18. Matsuki Y, Dan J, Fukuhara K, Ito T, Nambara T. Chem Pharm Bull. 1988; 36:1431-1436. [PubMed: 3416363]

19. Wynne, GM.; Wren, SP.; Lecci, C. Patent PCT Int Appl. WO 2008029168. 2008.

20. Walker, DP.; Piotrowski, DW.; Jacobsen, JE.; Acker, BA.; Myers, JK.; Groppi, VE, Jr. Patent PCT Int Appl. WO 2003070728. 2003.

21. Myers, JK.; Groppi, VEJ.; Piotrowski, DW. Patent PCT Int Appl. WO 2002016358. 2002.

22. Dell HD, Fiedler J, Kamp R, Kurz J, Wunsche C. Archiv Der Pharmazie. 1982; 315:416-422. [PubMed: 7103695]

23. Colquhoun HM, Williams DJ, Zhu Z. J Am Chem Soc. 2002; 124:13346-13347. [PubMed: 12418862]

24. Burgos CH, Barder TE, Huang XH, Buchwald SL. Angew Chem, Int Ed. 2006; 45:4321-4326.

25. Wolter M, Klapars A, Buchwald SL. Org Lett. 2001; 3:3803-3805. [PubMed: 11700143]

26. Lam MS, Lee HW, Chan ASC, Kwong FY. Tetrahedron Lett. 2008; 49:6192-6194.

27. Altman RA, Anderson KW, Buchwald SL. J Org Chem. 2008; 73:5167-5169. [PubMed: 18543973]

28. Xie XA, Cai GR, Ma DW. Org Lett. 2005; 7:4693-4695. [PubMed: 16209512]

29. Fors BP, Watson DA, Biscoe MR, Buchwald SL. J Am Chem Soc. 2008; 130:13552-13554. [PubMed: 18798626]

30. Fors BP, Davis NR, Buchwald SL. J Am Chem Soc. 2009; 131:5766-5768. [PubMed: 19348431]

31. Altman RA, Shafir A, Choi A, Lichtor PA, Buchwald SL. J Org Chem. 2008; 73:284-286. [PubMed: 18044928] 
32. Antilla JC, Baskin JM, Barder TE, Buchwald SL. J Org Chem. 2004; 69:5578-5587. [PubMed: 15307726]

33. Klapars A, Buchwald SL. J Am Chem Soc. 2002; 124:14844-14845. [PubMed: 12475315]

34. Zanon J, Klapars A, Buchwald SL. J Am Chem Soc. 2003; 125:2890-2891. [PubMed: 12617652]

35. Jiang L, Job GE, Klapars A, Buchwald SL. Org Lett. 2003; 5:3667-3669. [PubMed: 14507200]

36. Antilla JC, Klapars A, Buchwald SL. J Am Chem Soc. 2002; 124:11684-11688. [PubMed: 12296734]

37. Shelby Q, Kataoka N, Mann G, Hartwig JF. J Am Chem Soc. 2000; 122:10718-10719.

38. Schwarz N, Pews-Davtyan A, Alex K, Tillack A, Beller M. Synthesis. 2007:3722-3730.

39. Wang HF, Li YM, Sun FF, Feng Y, Jin K, Wang XN. J Org Chem. 2008; 73:8639-8642. [PubMed: 18842030]

40. Frlan R, Kikelj D. Synthesis. 2006:2271-2285.

41. Hartwig JF. Inorg Chem. 2007; 46:1936-1947. [PubMed: 17348724]

42. Backvall JE, Bjorkman EE, Pettersson L, Siegbahn P. J Am Chem Soc. 1984; 106:4369-4373.

43. Hartwig JF. Acc Chem Res. 1998; 31:852-860.

44. Mann G, Incarvito C, Rheingold AL, Hartwig JF. J Am Chem Soc. 1999; 121:3224-3225.

45. Strieter ER, Bhayana B, Buchwald SL. J Am Chem Soc. 2009; 131:78-88. [PubMed: 19072233]

46. Tye JW, Weng Z, Johns AM, Incarvito CD, Hartwig JF. J Am Chem Soc. 2008; 130:9971-9983. [PubMed: 18597458]

47. Sawyer JS, Schmittling EA, Palkowitz JA, Smith WJ. J Org Chem. 1998; 63:6338-6343. [PubMed: 11672267]

48. Paine AJ. J Am Chem Soc. 1987; 109:1496-1502.

49. Yin Y, Chen SW, Guo XX, Fang JH, Tanaka K, Kita H, Okamoto KI. High Perform Polym. 2006; 18:617-635.

50. Tamai S, Yamaguchi A, Ohta M. Polymer. 1996; 37:3683-3692.

51. Rose, D.; Meinigke, B. Ger Offen DE. 19719605. 1998.

52. Rudell DR, Mattheis JP, Fellman JK. J Agric Food Chem. 2005; 53:8382-8389. [PubMed: 16218691]

53. Fu XC, Liu ZQ, Li SM. Yaoxue Xuebao. 1994; 29:589-594.

J Am Chem Soc. Author manuscript; available in PMC 2011 July 6. 
<smiles>Cc1ccc(N2C(=O)c3ccc(C)cc3C2=O)c(C)c1</smiles>

treatment of Duchenne muscular dystrophy, patent no. WO 2008029168<smiles>CC1CC2CC(NC(=O)c3ccc(Oc4cccc(N)c4)cc3)C1C2</smiles>

treatment of schizophrenia or psychosis, patent no. WO 0216358<smiles>Cc1ccc2c(c1)NC(=O)CO2</smiles>

treatment of angiogenesis,patent no. WO 02085868<smiles>C[C@H](Oc1cccc(N)c1)c1ccc2c(N)nsc2c1</smiles>

therapeutic agent for endothelial disorder, patent no. WO 03087072<smiles>O=C(OCCO)c1cc(O)ccc1NCc1cccc(C(F)(F)F)c1</smiles>

etofenamate metabolites of animals<smiles>Cc1c(O)cc(Cl)c(N[C@H](C)c2ccccc2C(=O)O)c1Cl</smiles><smiles>Cc1ccc(Cl)c(NC(C)c2ccc(O)cc2C(=O)O)c1Cl</smiles><smiles>CC(=O)c1ccccc1NC(=O)c1c(Cl)cc(O)c(C(=O)O)c1Cl</smiles>

human urinary metabolites of meclomen, used in treatment of neurodegenerative disorder, patent no. WO 2004091522

Figure 1.

Biorelevant $\mathrm{O}$ - and $\mathrm{N}$-arylated aminophenol derivatives 
<smiles>O=C(O)c1ccccn1</smiles>

Picolinic Acid (1)

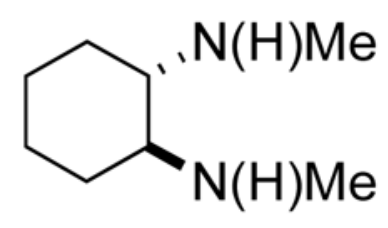

CyDMEDA (2)

Figure 2.

Ligands used in these studies for copper catalysis. 


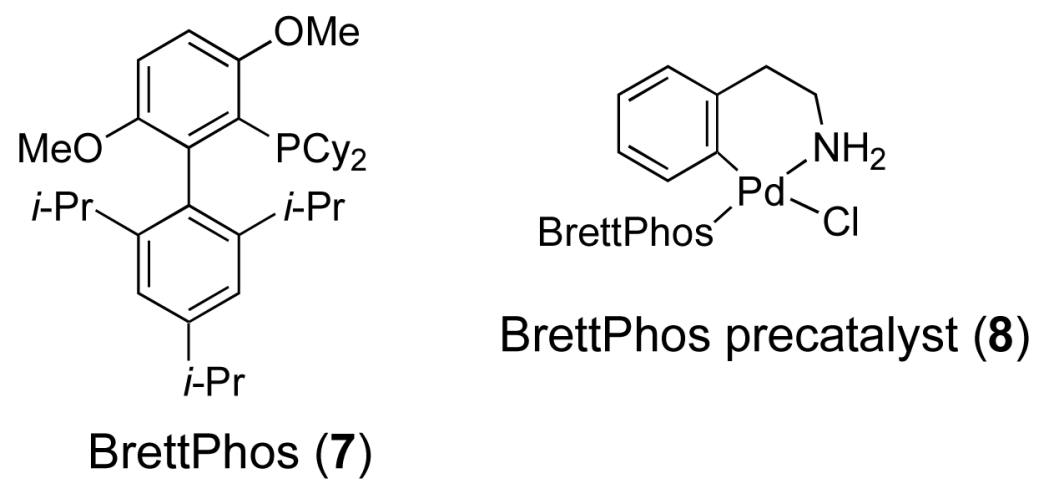

Figure 3.

Ligand and precatalyst used in these studies for palladium catalysis. 


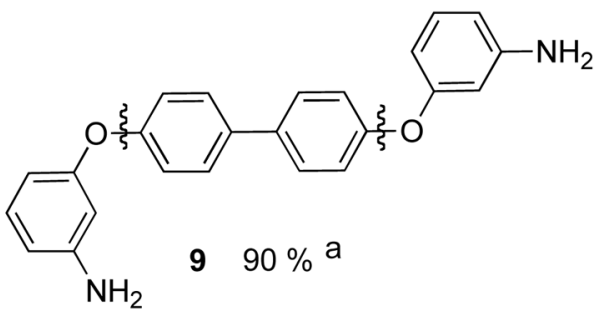

used in polyimide tubes<smiles>COc1ccc(Nc2cccc(O)c2)cc1</smiles><smiles>O=C(Nc1cccc(O)c1)c1ccccc1</smiles>

oxidative hair-dyeing agents<smiles>Nc1ccc(Oc2ccccc2N)cc1</smiles>

$1433 \%$ b

CYP450 inhibitor

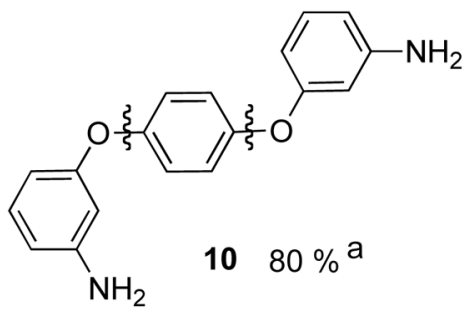

used in polyimide crystalline lens<smiles>Nc1cccc(Oc2cccc(N)c2)c1</smiles>

polymerization substrate<smiles>O=C(Nc1ccc(O)cc1)c1ccccc1</smiles>

scald protection<smiles>Nc1cccc(Oc2cccc(Br)c2)c1</smiles>

used in polyimide film

Figure 4.

Application of the $\mathrm{Cu}$-catalyzed selective $\mathrm{O}$-arylation of aminophenols to the preparation of interesting compounds $\mathrm{c}^{\mathrm{c}}$

a3.0 mmol 3-aminophenol, $10 \mathrm{~mol} \% \mathrm{CuI}, 20 \mathrm{~mol} \%$ 1, $90{ }^{\circ} \mathrm{C}$. ${ }^{\mathrm{b}} 2.0 \mathrm{mmol} 4$-aminophenol, 10 mol\% $\mathrm{CuI}, 20 \mathrm{~mol} \% \mathbf{2}, \mathrm{K}_{2} \mathrm{CO}_{3}$, butyronitrile, $70{ }^{\circ} \mathrm{C}$. ${ }^{\mathrm{C} I s o l a t e d ~ y i e l d, ~ a v e r a g e ~ o f ~ t w o ~ r u n s, ~} 1.2$ mmol 3-aminophenol, $1.0 \mathrm{mmol}$ aryl iodide, DMSO, $2.0 \mathrm{mmol} \mathrm{K}_{3} \mathrm{PO}_{4}$. 


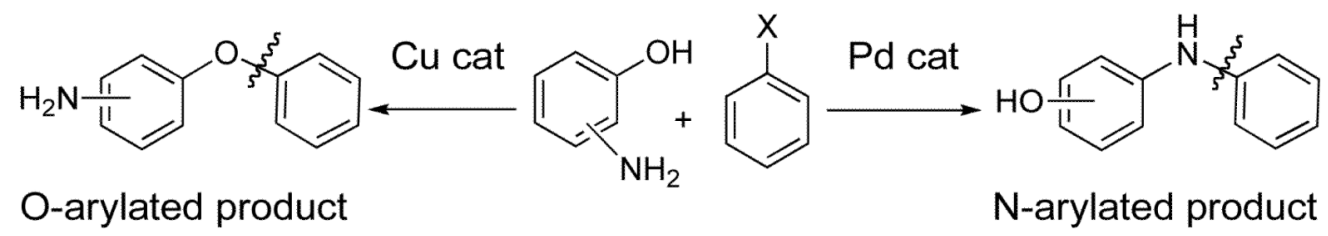

Scheme 1.

$\mathrm{Cu}$ - and $\mathrm{Pd}$-catalyzed $\mathrm{O}$ - and $\mathrm{N}$-arylation of aminophenol 


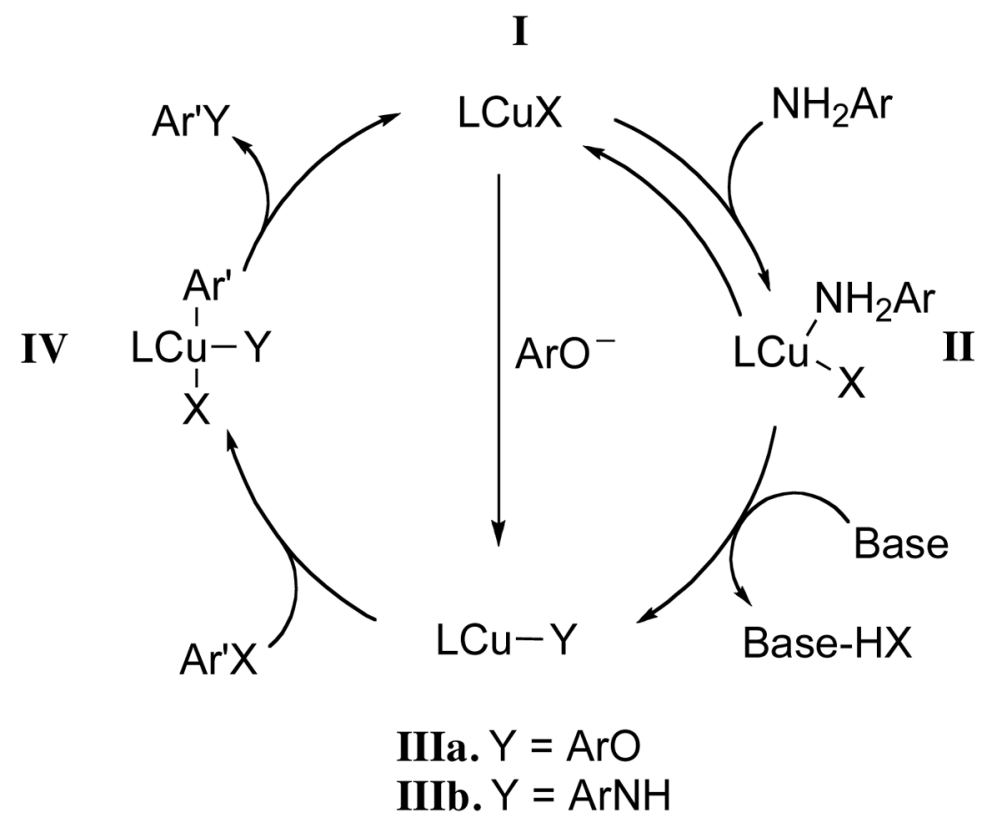

Scheme 2.

Catalytic cycle for $\mathrm{Cu}$-mediated coupling of aryl halides and nucleophiles. 

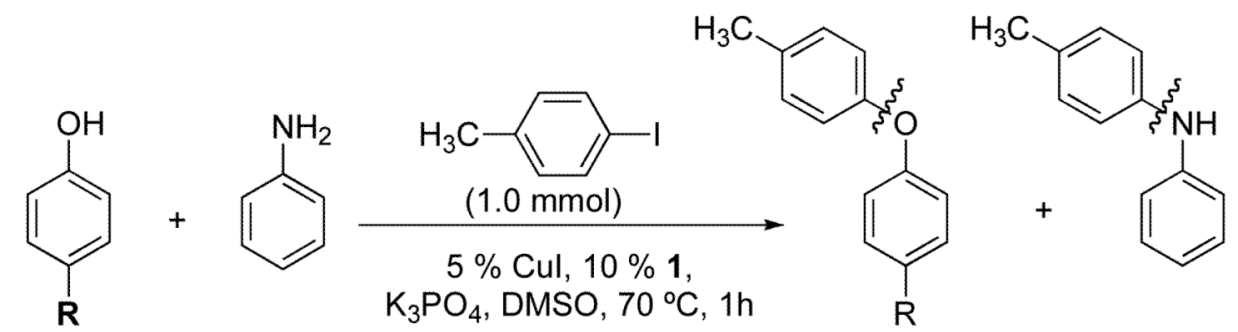

$(3.0 \mathrm{mmol})$

(3.0 mmol)

\begin{tabular}{lcc} 
& \multicolumn{1}{c}{$\mathbf{A 1}$} & A2 \\
$\mathrm{R}$ & GC-Yield & GC-Y \\
\hline $\mathrm{H}$ & 22 & -- \\
$t-\mathrm{Bu}$ & 25 & -- \\
$\mathrm{OCH}_{3}$ & 20 & - \\
$\mathrm{F}$ & 15 & -- \\
$\mathrm{NO}_{2}$ & -- & --
\end{tabular}

Scheme 3.

Competition experiments with 1:1 aniline: substituted phenol. 


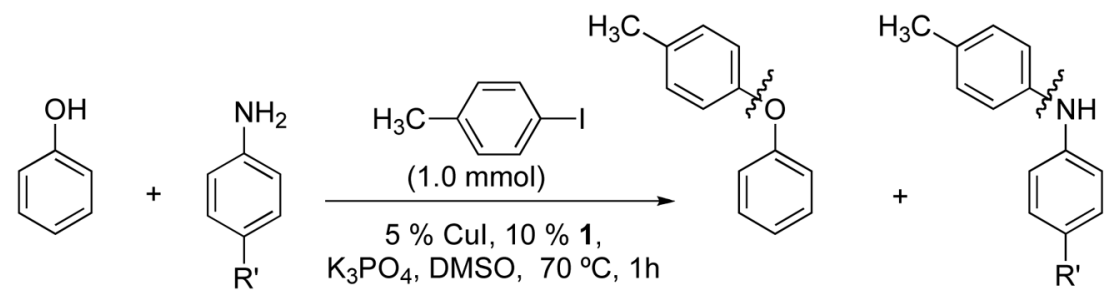

$(3.0 \mathrm{mmol}) \quad(3.0 \mathrm{mmol})$

B1

R' GC-Yield

$\begin{array}{lrl}\mathrm{H} & 23 & -- \\ t-\mathrm{Bu} & 22 & -- \\ \mathrm{OCH}_{3} & 22 & -- \\ \mathrm{CN} & 10 & 66 \\ \mathrm{NO}_{2} & 9 & 59\end{array}$

Scheme 4.

Competition experiments with 1:1 phenol:p-substituted aniline. 
Table 1

Comparison of various ligands in the coupling of 3-aminophenol with iodobenzene ${ }^{a}$

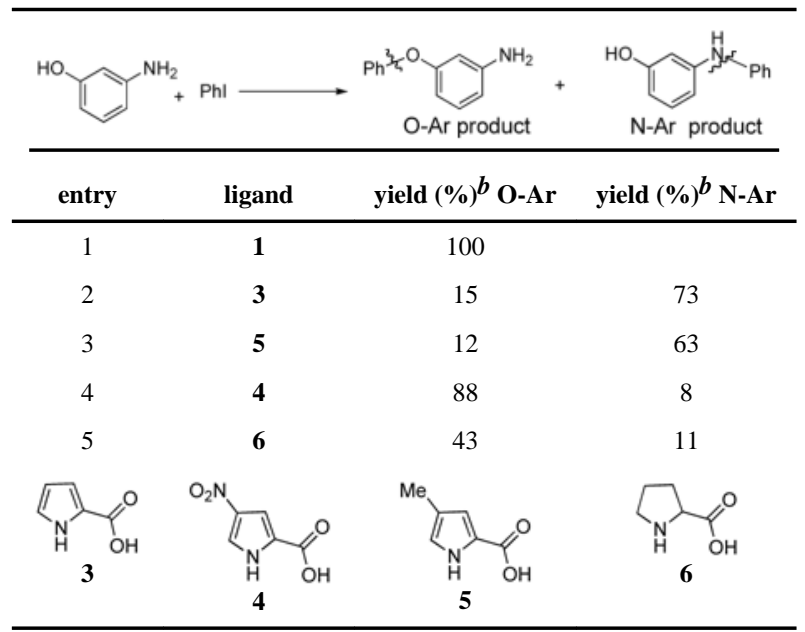

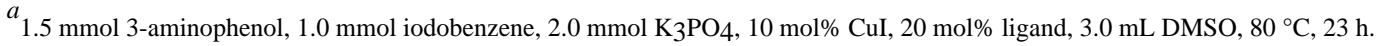

${ }^{b}$ GC-yield. 
Table 2

$\mathrm{Cu}$ - and $\mathrm{Pd}$ - catalyzed arylation of 3-aminophenols ${ }^{a}$

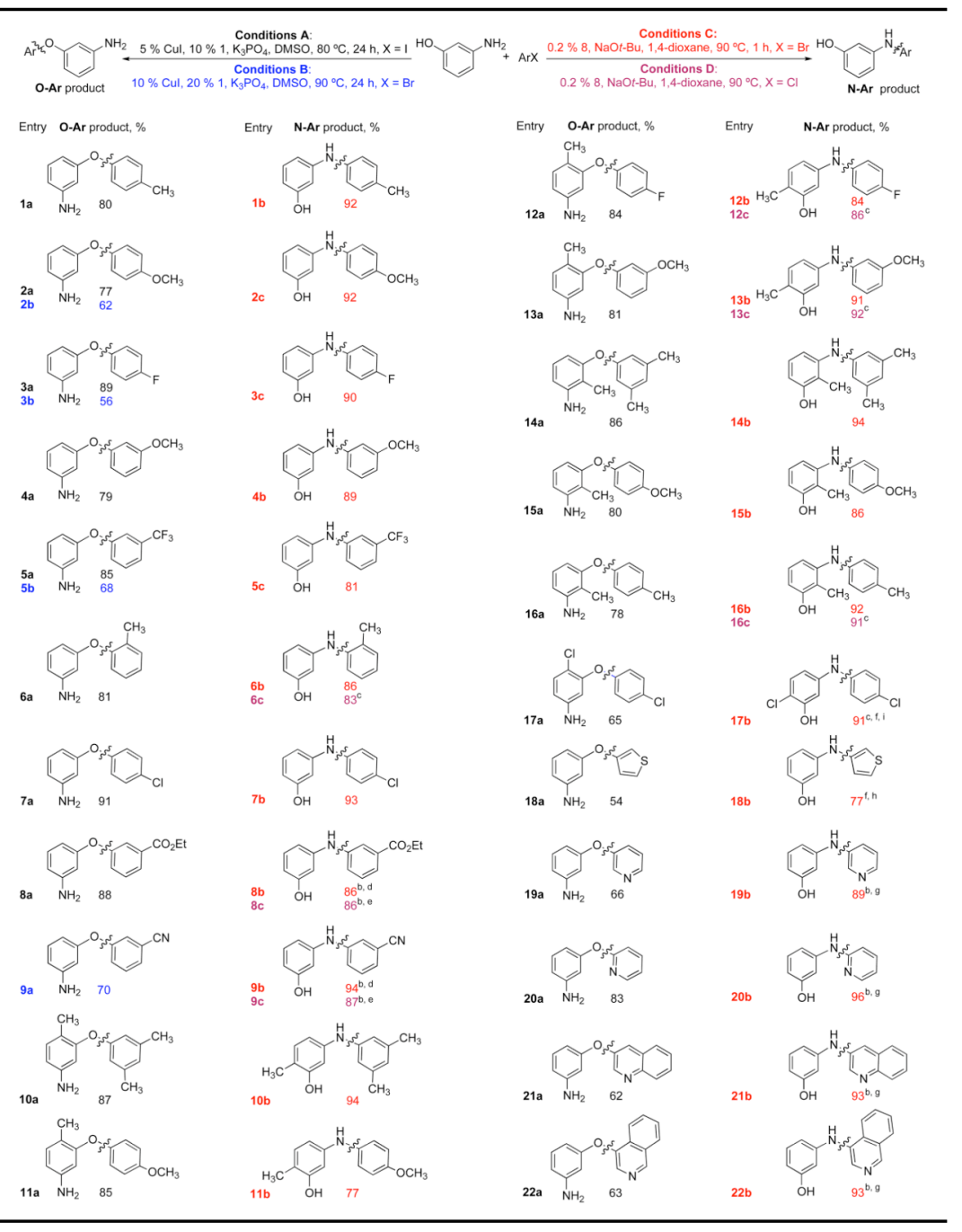

$a_{\text {Isolated yield, average of two runs. }}$

${ }^{b} \mathrm{~K}_{2} \mathrm{CO}_{3}, t-\mathrm{BuOH}, 110{ }^{\circ} \mathrm{C}$.

${ }^{c} 70 \mathrm{~min}$.

$d_{80 \mathrm{~min}}$.

$e_{90 \mathrm{~min} .}$

$f_{24 \mathrm{~h} \text {. }}$

$g_{1 \% 7,1 \% 8,24 \mathrm{~h} .}$

$h_{110}^{\circ} \mathrm{C}$.

${ }^{i}{ }_{1} \% \mathbf{8}$ 
Table 3

$\mathrm{Cu}$ - and $\mathrm{Pd}$ - catalyzed arylation of 4-aminophenols ${ }^{a}$

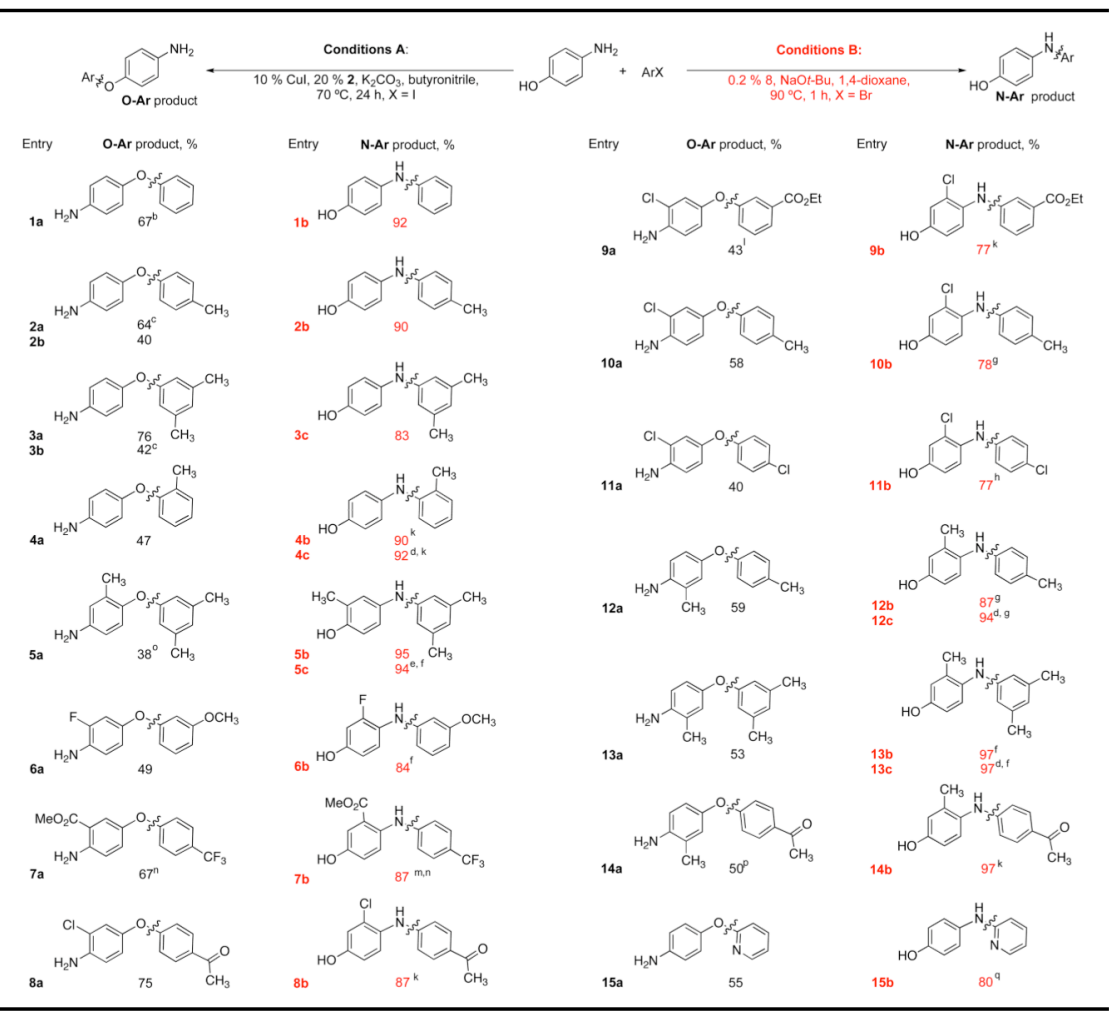

$a_{\text {Isolated yield, average of two runs. }}$

$b_{2 \%}$ of the N-arylated product was observed.

${ }^{c} \mathrm{ArBr}$.

${ }^{d} \mathrm{ArCl}$.

$e_{80 \mathrm{~min}}$

$f_{3 \mathrm{~h} \text {. }}$

$g_{24 \mathrm{~h} .}$

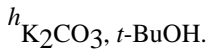

${ }^{i}{ }_{1 \% 8} 8$.

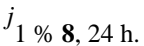

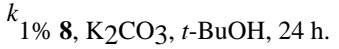

$l_{48 \mathrm{~h} .}$

${ }^{m} \mathrm{ArCl}, \mathrm{K}_{2} \mathrm{CO}_{3}, t-\mathrm{BuOH}, 3 \mathrm{~h}$.

$n_{0.5 \mathrm{mmol} \text { scale. }}$ 
${ }^{o} 16 \%$ of the $\mathrm{N}$-arylated product was observed.

$p_{3 \%}$ of the $\mathrm{N}$-arylated product was observed.

$q_{1 \%} 7,1 \% 8, \mathrm{~K}_{2} \mathrm{CO}_{3}, t-\mathrm{BuOH}, 110{ }^{\circ} \mathrm{C}, 24 \mathrm{~h}$. 
Table 4

$\mathrm{N}$-arylation of 2-aminophenol ${ }^{a}$

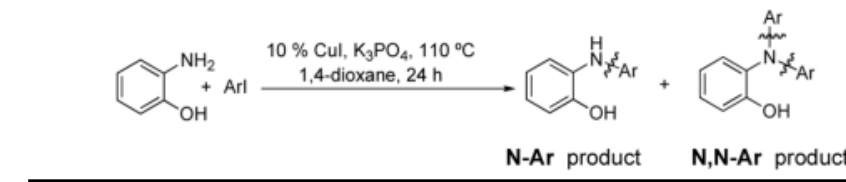

\begin{tabular}{ccccc} 
aminophenol & arene & entry & yield $(\%)^{\boldsymbol{b}} \mathbf{N}-\mathrm{Ar}$ & yield $(\%)^{\boldsymbol{b}} \mathbf{N}, \mathbf{N}$-Ar \\
\hline & 1 & 92 & 3
\end{tabular}

- $-\mathrm{CH}_{3} \quad 2 \quad 90$

-

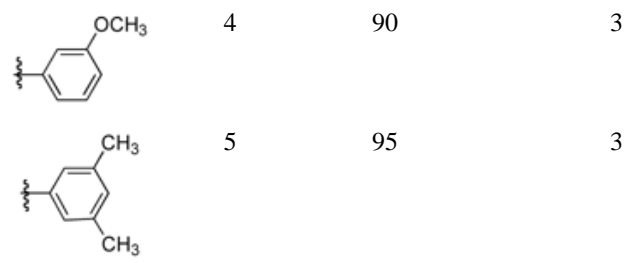

(

$a_{\text {Isolated yield, average of two runs. }}$

${ }^{b} \mathrm{ArBr}$. 